\title{
Romantic relationship satisfaction in emerging adulthood
}

\author{
Funda Barutçu-Y1ldırım (iD \\ Middle East Technical University, Faculty of Education, Department of Educational Sciences, Ankara, \\ Turkey, barutcu@metu.edu.tr \\ Gökçen Aydın \\ Hasan Kalyoncu University, Faculty of Education, Guidance and Psychological Counseling Department, \\ Gaziantep, Turkey, gokcenaydn@gmail.com \\ Gökçe Sancak-Aydın (iD) \\ Yozgat Bozok University, Faculty of Education, Guidance and Psychological Counseling Department, \\ Yozgat, Turkey, sancakag@gmail.com
}

\begin{abstract}
The aim of the study was to explore the extent to which the length, status and importance of current romantic relationship, the number of previous romantic relationship, as well as individual factors, such as levels of self-compassion, and anxiety about social appearance, are predictors of the romantic relationship satisfaction of young adults. The study included 284 university students but 34 of them were removed for several reasons and analysis was carried out with 250 participants $(59.6 \%$ female, $40.4 \%$ male). Relationship Assessment Scale, Self-Compassion Scale, Social Appearance Anxiety Scale, and demographic information form were used to collect data. Hierarchical regression analysis results showed that the importance of the current romantic relationship, the number of previous romantic relationships, and levels of self-compassion were positive predictors but the length and the status of the relationship, along with the level of anxiety regarding social appearance were not significant predictors of romantic relationship satisfaction. The model explained $37 \%$ of the variance in the romantic relationship satisfaction of young adults.
\end{abstract}

Keywords: Emerging adulthood, Relationship characteristics, Romantic relationship satisfaction, Selfcompassion, Social appearance anxiety

\section{Beliren yetişkinlikte romantik ilişki doyumu}

ÖZ Bu çalışmanın amacı, şu anki romantik ilişkinin süresi, statüsü, önemi ve önceki romantik ilişkilerin toplam sayısı gibi çeşitli ilişki özellikleri ile birlikte öz şefkat ve sosyal görünüş kaygısı gibi bireysel faktörlerin, beliren yetişkinlerin romantik ilişki doyumunu ne ölçüde yordadığını araştırmaktır. Araştırmaya 284 üniversite öğrencisi katılmıştır ancak çalışmaya katılan öğrencilerden 34'ü çeşitli nedenlerle araştırma kapsamı dışında bırakılmıştır. Bu nedenle analizler, 250 öğrencinin verileri (\%59.6 kadın, \% 40.4 erkek) kullanılarak yapılmıştır. Veri toplama aracı olarak, İlişki Doyumu Ölçeği, Öz Şefkat Ölçeği, Sosyal Görünüş Kaygısı Ölçeği ve araştırmacılar tarafından geliştirilen demografik bilgi formu kullanılmıştır. Hiyerarşik regresyon analizi bulgularına göre, devam eden ilişkinin önemi, daha önceki ilişkilerin sayısı ve öz şefkat beliren yetişkinlerin romantik ilişki doyumunu pozitif yönde yordayan değişkenlerdir. Ancak şu anki romantik ilişkinin süresinin, statüsünün ve sosyal görünüş kaygısının beliren yetişkinlerin romantik ilişki doyumunu anlamlı bir şekilde yordamadığı bulunmuştur. $\mathrm{Bu}$ çalışma kapsamında test edilen model, beliren yetişkinlerin romantik ilişki doyumunu açılayan varyansın \%37'sini açıklamaktadır.

Anahtar

Beliren yetişkinlik, Illişki özellikleri, Öz-şefkat, Romantik ilişki doyumu, Sosyal görünüm kaygısı

Citation:

Barutçu-Yıldırım, F., Aydın, G., \& Sancak-Aydın, G., (2021). Romantic relationship satisfaction in emerging adulthood. Turkish Journal of Education, 10(4), 319-332 https://doi.org/10.19128/turje.874516 


\section{INTRODUCTION}

Relationship satisfaction is a foremost topic of research in current intimate relationship literature. Relationship satisfaction is defined as an individual's general level of satisfaction in regard to his/her relationship (Mattson et al., 2013). A healthy and stable intimate relationship is described as being key to an individual's happiness (Coyne et al., 2011) since a person usually first experiences romantic love during adolescence or even earlier. Arnett (2000) describes the period of emerging adulthood as being between ages 18 and 25. The use of the phrase emerging adulthood in this study therefore refers to the period of life that is also often described as being one's college years. This period is particularly important in the subsequent development of healthy romantic relationships, as experience gained during the period of emerging adulthood affects the quality and the level of commitment to subsequent romantic relationships (Furman, 2002). Furthermore, there is the tendency to become involved in romantic relationship during this stage of life (Carver et al., 2003).

Regardless of identity (Roisman et al., 2004), or whether the relationship is heterosexual, homosexual, or platonic, the literature indicates that intimacy in romantic relationships usually first occurs during emerging adulthood (Zimmer-Gembeck \& Petherick, 2006). Arnett (2000) places high importance on the period of emerging adulthood because it is usually when love, work and general perspectives on life are radically shaped. Barry et al. (2009) concur, and conclude that romantic relationships are often more important than friendship for emerging adults. Berscheid et al. (1989) suggest that among college students, partners in romantic relationships have the closest relationship compared to their relationships with others, and this is simply due to the fact that relationships during emerging adulthood can be considered as being more intimate and rational, as compared to the romantic relationships of adolescents. Furthermore, during the period of emerging adulthood, individuals can evaluate their relationships and try to understand whether the qualities and experiences of their partners satisfy their intimacy and commitment needs (Clark \& Beck, 2011). Arnett (2000) emphasizes that the commitment, in terms of time, sharing of feelings etc., that is made in relationships that occur during emerging adulthood in order to find the love of one's life, is an important factor for determining relationship satisfaction.

Previous experiences of relationships are influential on how satisfied a person is with a current relationship. Norona et al. (2017) investigated the lessons that emerging adults take from their previous relationships. The study indicated that emerging adults generally group their experiences in terms of social cognitive maturity, romantic agency, and coherence, although differences do exist in terms of gender. There is extensive literature on the variables that are related to relationship satisfaction. More specifically, relationship satisfaction is related with life satisfaction (Roberts \& Davis, 2016), psychological well-being (Epstein \& Baucom, 2002), problem solving skills (Metts \& Cupach, 1990), empathic behavior and secure attachment style (Pintado\& Mendoza, 2016), emotional intelligence (Malouff et al., 2014; Mavruk Özbiçer, \& Atıc1, 2018), intimacy dating goals (Zimmer-Gembeck \& Petherick, 2006), partners' time perspectives (Stolarski et al., 2016), partner phubbing (the act of snubbing someone you are talking with in person in favor of your phone) (Roberts \& David, 2016), narcissism (Wurst et al., 2017), and depression (Cramer, 2004; Roberts \& David, 2016).

\section{Relationship Characteristics and RRS}

There are various characteristics of a relationship which have an impact on romantic relationship satisfaction (RRS). In the present study, four of the relationship characteristics -the length of RR, the importance of RR, the number of previous RR, and RR status- were considered. To begin with, the previous studies yield contradictory findings regarding the relationship between the length of RR and RSS. For example, Rahaman (2015) points that the length of the relationship does not significantly correlated with RRS. Mavruk Özbiçer and Atıcı (2018) agree and argue that RRS does not correspond to changes in the length of the relationship. However, Saraç et al. (2015) conclude the opposite, i.e. that 
the length of the relationship is indeed positively correlated with RRS. More specifically, the findings demonstrate that levels of satisfaction increase according to the length of the relationship. Secondly, the importance of RR is considered as a possible contributing relationship characteristic in RRS. Although none of the current studies have directly examined connections between the importance attached to the relationship and RRS, 'future time orientation' and 'commitment' literature provide indirect support for this possible relationship. The need for future commitment and investment into relationship include attaching importance to the relationship. As a matter of fact, Sakall1-Ugurlu (2003) found that individuals who had higher future orientation had higher relationship satisfaction and females showed more future oriented tendencies compared to males. Nock (1995) mentioned the lower quality of relationship as an inevitable result of low commitment. Additionally, Wiik et al. (2009) tested relationship seriousness of married couples and cohabiters where relationship seriousness is described as intentions to marry. Even though these concepts cannot be a counterpart for the importance attached to relationship, they, in a way, represent a general view of doing something valued for a better future of relationship. The purpose of current study is therefore to contribute to this gap in RRS research by shedding light on the predictor role of importance in a relationship. Thirdly, another correlating factor is identified by Saraç et al. (2015), who demonstrate that relationship status (engaged or dating) is also a predictor of RRS. They show that people feel more satisfied with a relationship when the participants are engaged, rather than merely dating. These findings are confirmed by Kırıt Gülaydın and Semerci (2018), who point that dating couples are less satisfied with their relationships, as compared to engaged and married couples. Fourthly, an essential connection to mention is the role of previous experiences on RRS. Frazier and Esterly (1990) conclude that while the number of previous relationships is a predictor of RRS for women, the same could not be said for men. In other words, it can be seen that learning from past experiences differs according to gender.

\section{Self-Compassion and RRS}

In addition to the characteristics of a relationship, self-compassion has a significant effect on RRS. Selfcompassion includes self-kindness, common humanity, and mindfulness. It is the showing of kindness and understanding without being judgmental towards oneself (Neff, 2003b). While the concept of selfcompassion is positively related with well-being (Neff \& McGehee, 2010), it is negatively related with depression and anxiety (Neff et al., 2008). Among the various related concepts of self-compassion, the level of satisfaction in a relationship, and the existence of a healthy and fulfilling romantic relationship, are both strongly associated with self-compassion (Neff \& Beretvas, 2013). The researchers found that individuals in heterosexual relationships who had high self-compassion had a stronger emotional connection with their partners, which is likely to influence their RRS level. On the other hand, selfcritical individuals were found to be generally more dissatisfied in romantic relationships (Lynch et al., 2001). The reason for this, according to Baker and McNulty (2011), is that the comfort zone provided by self-compassion allows individuals to feel better about themselves and their partner.

Neff and Beretvas (2013) suggest that there are many ways to describe the benefits of self-compassion in romantic relationships, as self-compassion not only creates a constructive environment for dealing with any problems that might arise in a romantic relationship, it also empowers mutual acceptance. Moreover, in a study conducted with undergraduate students, Baker and McNulty (2011) find that selfcompassion is associated with a woman's level of motivation in correcting their interpersonal mistakes. Similarly, Neff and Beretvas (2013) reached the conclusive finding that self-compassionate people tend to exhibit more accepting manners toward their partners, as well as be more intimate in their relationships because self-compassionate individuals are prone to be more open in accepting their mistakes. A crucial point is that self-compassionate individuals are likely to be interested in both their and their partner's investment in the relationship, and that this leads to a better comprehension of any conflicts in the relationship. Neff and Davidson (2016) suggest that self-compassion is a way of showing kindness to experience suffering. From this point of view, self-compassionate individuals are more open-minded regarding any problems in the relationship; and this means that they are likely to be more satisfied in their romantic relationships. 


\section{Social Appearance Anxiety and RRS}

Another factor that influences RRS is social appearance anxiety, which is concern over the possible negative evaluation of others about one's appearance (Hart et al., 2008). There is no doubt that physical attractiveness has an important role in social relationships, and that if the individual perceives him/herself as being inadequately attractive, and this results in the avoidance of social interactions, s/he may experience social appearance anxiety (Titchener \& Wong, 2015). The extended literature points out that social appearance anxiety is related with social anxiety disorder (Levinson et al., 2013), eating anxiety (Levinson \&Rodebaugh, 2012), perfectionism (Kang et al., 2013), and negative body image (Claes et al., 2012). Moreover, it is reported that body dissatisfaction is positively related with depression (e.g. Özcan et al., 2013; Szymanski \& Henning, 2007) and negatively related with selfesteem (Grossbard et al., 2009), life quality (Ganem et al., 2009), self-compassion (Wasylkiw et al., 2012) and social appearance anxiety (Levinson \& Rodebaugh, 2012).

Furthermore, an extensive amount of research has been conducted on self-compassion and body image. Gouveia et al. (2019) have identified the indirect effect of self-compassion on emotional eating among adolescents. More specifically, they have shown that the more evidence there is of self-compassion skills, the less likely the individual is to indulge in emotional eating due to the presence of emotional regulation skills. Similarly, Siegling and Delaney (2013) have found that women who have low selfcompassion have lower body image satisfaction. These studies indicate that social appearance anxiety can be an important variable in determining an emerging adult's RRS self-esteem, and that selfcompassion can influence relationships. In addition, a qualitative research study conducted with young adults who had negative body image in early adolescence, but turned this negative image into a positive body image when becoming an adult, concluded that people changed their image when they found a new social context. The study went on to suggest that an adolescents' physical appearance was not only associated with body image (Gattario \& Frisén, 2019). The related literature also suggests that social appearance anxiety might be developed as an inner process, rather than being due to external causes.

Considering the importance of RRS in emerging adulthood, in relation to the aforementioned literature, it is important to investigate factors of RRS such as relationship characteristics, self-compassion and social appearance anxiety. The method used for this investigation was to first enter relationship characteristics into the initial step, or Model 1 . Self-compassion was the subsequently entered as the second step, namely Model 2, and finally, social appearance anxiety was included to Model 3 as the third step. The following hypotheses were investigated based on the related literature:

H1: The length and the importance of RR, the number of previous RR, and RR status, are all positive significant predictors of the RRS of emerging adults.

$\mathrm{H} 2$ : After controlling for relationship characteristics, self-compassion is a positive significant predictor of the RRS of emerging adults.

H3: After controlling for relationship characteristics and self-compassion, social appearance is a negative significant predictor of the RRS of emerging adults.

\section{METHOD}

\section{Participants}

In this correlational research, purposive sampling was used to select participants from two state universities in the central region of Turkey. The criteria for participating in the study was being in a romantic relationship, although 'relationship' was not defined by the researchers but left to the participants' own perceptions. For sample size, Green' s formula $(\mathrm{N}>50+8 \mathrm{p} ; \mathrm{p}=$ number of predictor variable) was taken into consideration (Green, 1991). The initial sample of the study included 284 participants. During data cleaning, a total of 34 participants were removed for four different reasons. 
Firstly, the study was limited to emerging adults aged between 18 and 25, and so twenty-one participants who were aged over 25 were removed. Secondly, five married participants were removed because marital satisfaction was not within the scope of this study. Thirdly, three participants who completed most of the scales' items with a single value were also removed; and finally, five participants who did not fill out more than the half of the scale were left out of the study. A total of 250 students ( 149 females, 101 males) took part in this study. 110 (44\%) majored in education, 68 (27.2\%) in engineering, 48 (19.2\%) in arts and sciences, $11(4.4 \%)$ in economic and administrative sciences, $1(0.4 \%)$ student had a different major and $10(4 \%)$ participants did not specify which faculty they were from.

Participants were aged between 18 and $25(M=21.53, S D=1.67)$. The average length of the relationship was 23.07 months $(S D=21.67)$. Participants rated the importance of their relationship on a 7-point scale (1: not important to 7: very important), and the average importance was $5.97(S D=1.3)$. The number of previous relationships varied between 1 and $14(M=3.06, S D=2.39)$. Two hundred and twenty-eight (91.2\%) of the participants reported that they had a date, and $22(8.8 \%)$ were engaged.

\section{Data Collection Tools}

The Relationship Assessment Scale (RAS) was developed to measure RRS (Hendrick, 1988). One factor of the scale includes 7 items rated on a 7-point scale (1: strongly disagree to 7: strongly agree). A higher score represents higher RRS. The alpha coefficient was found to be .91 for the original version of the scale (Vaughn \& Baier, 1999). Curun (2001) adapted RAS into Turkish and found Cronbach's alpha coefficient as 0.86 . The current study revealed a Cronbach's alpha of. 88 .

The Self-Compassion Scale (SCS) was developed by Neff (2003a) to understand levels of selfcompassion. The scale includes 26 items on a 5-point scale (1: almost always to 5: almost never). The higher the score, the higher the level of self-compassion. The original version of the SCS has six factors (self-kindness, self-judgment, awareness of common humanity, isolation, mindfulness and overidentification) but in the Turkish version of the scale, Deniz et al. (2008) found that a six factor structure did not fit the sample, and so items were loaded onto a single factor. They also removed two items, because the total correlation of these items was less than.30. For this reason, the Turkish version of SCS includes 24 items rather than 26. Deniz et al. (2008) reported the internal consistency coefficient of the scale as being. 89 . This study revealed a Cronbach's alpha of.90 on a single-factor scale.

Finally, the Social Appearance Anxiety Scale (SAAS) (Hart et al., 2008) was used to assess social appearance anxiety. SAAS is a single factor scale and includes 16 items rated on a 5-point scale1: not at all to 5: extremely). A higher score indicates higher levels of social appearance anxiety. The internal reliability coefficients of the SAAS were found to be $.94, .95$ and .94 in three different samples (Hart et al., 2008). Doğan (2010) adapted the SAAS into Turkish and reported Cronbach's alpha coefficient as being .93 for the Turkish version. The current study pointed a Cronbach's alpha of.94.

\section{Procedure}

This study was approved by Middle East Technical University Human Subjects Ethics Committee with a protocol number of 2007-EGT-032 on March 8, 2017. Data was collected from two universities. In order to collect data in classroom settings with a paper and pencil format, we contacted with the instructors; then, we made a schedule with the instructors who agreed to collaborate. We explained the aim of the study, anonymity and voluntarily participation principals of the research to the participants, they filled out the scales during regular class. After obtaining participants' informed consent, instruments were completed in approximately 20 minutes.

\section{Data Analysis}

Prior to data analysis, missing values were calculated and they were found to be less than 5\%. Missing value analysis was therefore not implemented, due to, as pointed out by Tabachnick and Fidell (2007), 
missing values of less than 5\% not having an effect on overall results. Out of the 250 items of data taken into consideration during the data analysis, 160 were collected from one university, and 90 from another. An independent t-test was conducted to determine the difference between the universities, with no significant difference being found $\mathrm{t}(244)=1.25, \mathrm{p}>.05$. Before hierarchical regression was conducted, the assumptions of this statistical analysis [sample size, homoscedasticity, normally distributed errors, independent errors, multicollinearity, linearity, influential observations (Tabachnick \& Fidell, 2007)] were checked, and no violation of the assumptions was found. Finally, hierarchical regression analysis was conducted to test the extent that relationship characteristics, self-compassion, and social appearance anxiety were predictors of RRS. This was based on the comprehensive literature which points to the individual effects of relationship characteristics, self-compassion, and social appearance anxiety on RRS.

\section{RESULTS}

Table 1 presents the summary of hierarchical regression analysis results. In Model 1, H1 has been tested and the findings show that it was partially met. The importance of the romantic relationship $(\beta=0.59$, $p<0.001)$, and the number of previous romantic relationships $(\beta=0.12, p<0.05)$, were seen to be significant positive predictors of RRS. However, the length of the relationship $(\beta=0.04, p>0.05)$ and the relationship status $(\beta=0.06, p>0.05)$ were found to be non-significant predictors.

In Model 2, self-compassion was added and, in line with $\mathrm{H} 2$, it was found to be a significant positive predictor $(\beta=0.16, p<0.05)$. Lastly, in Model 3, H3 was tested, but the findings did not support the hypothesis, as social appearance anxiety was found to be a non-significant predictor. $(\beta=-.09, p>.05)$. The overall model accounted for $37 \%$ of the variance in RRS. Cohen's f 2 was used for measuring effect size $(0.02=$ small, $0.15=$ medium, large $=0.35)\left(\right.$ Cohen, 1988). For the overall model, Cohen's $f^{2}$ was calculated as 0.58 which indicated large effect size. The partial variance of the importance of the romantic relationship was $27 \%$ and Cohen's $f^{2}$ of the importance of the romantic relationship was found as 0.37 pointing to a large effect size. Furthermore, the partial variance of the number of previous romantic relationships was found as $1 \%$ and Cohen's $f^{2}$ value was reported as 0.01 , which indicated no effect. Lastly, the partial variance of self-compassion was found as $0.3 \%$ and Cohen's $f^{2}$ was 0.03 which showed a medium effect.

Table 1.

Results of hierarchical regression analysis predicting RRS $(N=250)$

\begin{tabular}{|c|c|c|c|c|c|c|c|c|c|}
\hline \multirow[b]{2}{*}{ Variable } & \multicolumn{3}{|c|}{ Model 1} & \multicolumn{3}{|c|}{ Model 2} & \multicolumn{3}{|c|}{ Model 3} \\
\hline & $B$ & $S E B$ & $\beta$ & $B$ & $S E B$ & $\beta$ & $B$ & $S E B$ & $\beta$ \\
\hline Length of the RR & 0.02 & 0.03 & .04 & 0.01 & 0.03 & .02 & 0.01 & 0.03 & .02 \\
\hline Importance of the RR & 0.53 & 0.05 & $.59 * * *$ & 0.53 & 0.05 & $.59 * * *$ & 0.52 & 0.05 & $.58 * * *$ \\
\hline RR Status & 0.22 & 0.21 & .06 & 0.16 & 0.21 & .04 & 0.13 & 0.21 & .03 \\
\hline Number of previous RR & 0.06 & 0.03 & $.12 *$ & 0.05 & 0.03 & .11 & 0.05 & 0.03 & $.12 *$ \\
\hline Self-compassion & & & & 0.30 & 0.10 & $.16 * *$ & 0.22 & 0.11 & $.12 *$ \\
\hline Social appearance anxiety & & & & & & & -0.14 & 0.10 & -.09 \\
\hline $\mathrm{R}^{2}$ & \multicolumn{3}{|l|}{.33} & \multicolumn{3}{|l|}{.36} & \multicolumn{3}{|l|}{.37} \\
\hline $\mathrm{F}$ for change in $\mathrm{R}^{2}$ & \multicolumn{3}{|c|}{$29.78 * * *$} & \multicolumn{3}{|c|}{$26.57 * * *$} & \multicolumn{3}{|c|}{$22.61 * * *$} \\
\hline
\end{tabular}

Note: $\mathrm{RR}=$ romantic relationship; $* p<.05, * * p<.01, * * * p<.001$. 


\section{DISCUSSION AND CONCLUSION}

This study aimed at exploring the predictor role of relationship characteristics, self-compassion, and social appearance anxiety in RRS. The results showed that the importance of the romantic relationship, as well as the number of previous romantic relationships, were significant positive predictors. However, the length of the relationship and the relationship status were non-significant in predicting RRS. Additionally, self-compassion was a significant positive predictor, while social appearance anxiety was a non-significant negative predictor in explaining RRS.

A significant contribution of this study was to highlight the connection between the importance of the relationship, and RRS, as the importance attached to the relationship contributed most to the model. As far as we know, none of the previous studies directly examine the relationship between these two variables even though future commitment and future orientations are meant to be partially included in describing importance attached to relationship (e.g. Sakalli-Ugurlu, 2003). The previous literature showed higher commitment resulted in higher relationship satisfaction (Bucher et al., 2019). The findings of the present study indicate that emerging adults who attached greater importance to their relationship had higher RRS. The results may imply that, in addition to the well-known relationship types (marriage, engagement, etc.), todays' emerging adults have a richer repertoire of relationship choices, including casual dating, open relationships, long-distance relationships, asexual relationships, amongst others. In these types of relationships, a couples' focus, and the level of importance attached to the relationship, may vary. For instance, in a casual dating relationship, it is unlikely that members will pay much attention to the maintenance, or even the importance, of the relationship. Furthermore, in today's complicated world, where academic work, career choices, economic issues, family and friendship relationships, volunteering, daily routine, social media, and so on, are constantly being juggled, there are innumerous things that may distract and tire emerging adults'. In such a confused environment, romantic relationships are under more pressure to attract attention. Under such conditions, the finding that the greater the importance of the relationship, the greater the RRS, would be a valuable contribution to RRS literature.

Besides the significant predictors, the length of the relationship and relationship status were found as non-significant predictors. In other words, these two relationship characteristics did not contribute in explaining variance in RRS. Firstly, the present study pointed that the RRS did not change according to the length of the relationship. This finding was parallel with the previous studies that showed no correlation between the length of the relationship and RRS (i.e. Mavruk Özbiçer \& Atıc1, 2018; Rahaman, 2015; Sharma \& Ahuja, 2014). However, it contradicts with the study indicating the longer the relationship means the higher satisfaction (i.e. Saraç et al.). This finding can be interpreted that rather than the length of the relationship, how time was spent by the partners should be taken into account. Secondly, relationship status was found as a non-significant predictor of RRS. Although previous studies reveal differences between dating, engaged and married couples in term of RRS (Kirıt Gülaydın \& Semerci, 2018; Saraç et al., 2015; Taormina \& Ho, 2012). When previous literature was taken into consideration, engaged couples seemed to be more satisfied compared to dating or married couples. However, in this study, RRS did not change according to being engaged or dating. One possible explanation for this finding might be that being engaged or dating would have a similar meaning as a relationship status in the current sample.

The current study indicates that self-compassion is the second most contributing variable to RRS, which increased proportionally to self-compassion. This finding was complementary with the growing body of literature that shows self-compassionate people have better personal and relational functioning. Selfcompassion is positively related with health and well-being (Biber \& Ellis, 2019; Bluth \& Blanton, 2014; Neff et al., 2008), body satisfaction (Pullmer et al., 2019), mindfulness (Svendsen et al., 2017), emotional intelligence (Castilho et al., 2017), and self-esteem (Neff \& Vonk, 2009). However, selfcompassion was negatively associated with depression and rumination (Svendsen et al., 2017), social 
anxiety (Makadi \& Koszycki, 2020), perceived stress (Bluth et al., 2017), vulnerable narcissism and aggression (Barry et al., 2015). It is clear that people who are at peace with themselves, and who are self-compassionate, are expected to function better in their relationships (Jacobson et al., 2018). Baker and McNulty (2011) revealed that with the moderating effect of conscientiousness, more selfcompassionate and conscientious individuals spend more effort addressing mistakes within the relationship, and generally feel more satisfied within it. This trait was equally apparent in both males and females.

There is extensive literature on body image satisfaction in emerging adulthood (e.g. Goswami et al., 2012; Paap \& Gardner, 2011; Sira \& White, 2010). However, the inadequacy of studies examining the relationship between social appearance anxiety and RRS is surprising, and so the results obtained should be considered carefully. One important factor to bear in mind is culture, and Turkish culture might have played a crucial role in this study (Kağıtçıbaş1, 2010). To illustrate, eastern cultures, including Turkey, tend to interfere more in young adults' life choices, including their appearance or relationships. Likewise, in Turkish culture, the majority of university students leave their family for the first time when they start university and might subsequently feel a sense of freedom in their life choices as the pressure of the family is removed. This freedom also includes social appearance as more traditional families may not allow children to have signs of individuality, such as piercing, tattoos or alternative clothes. Furthermore, Gattario and Frisén (2019) indicated that people often changed their image when in a new social context, such as at college. Research also shows that the social and familiar dimension had an important influence while defining the self in Turkish adolescence (Yerin-Güneri et al., 1999). Many college students who experienced living on their own during their college life, may also have been able to fulfill their own physical choices during this period in relation to clothing, piercing, and so on, without any familial and social influence.

Certain limitations must be taken into consideration. First, the participants were emerging adults from only two universities, and so results for other populations are unknown. In other words, no claim is made that the results can be generalized to all emerging adults. Second, the self-report nature of the study can be considered as a further limitation, as there are several reasons why students may have provided biased responses regarding their relationship. By necessity, the results had to interpreted by considering that they were an actual reflection of the true nature of the relationships. It is worth mentioning that as the study was correlational, and so the findings of this study do not infer causality i.e. only associations between variables were reported. There is therefore a need for further cross-sectional and longitudinal studies to be conducted to investigate the predictors of the RRS of emerging adults. Moreover, there is also a need to find the reason behind the unexplained variance in the RRS of emerging adults by including other related RSS variables.

To conclude, the results suggest that the importance of the romantic relationship, the number of previous romantic relationships, and self-compassion, were all significant positive predictors of RRS. Also, the results reveal that the importance of the relationship contributed most to the model, with self-compassion making the second highest contribution. On the other hand, the number of previous romantic relationships made the least contribution. The link between self-compassion, social appearance anxiety and RRS provides an avenue for further research, such as intervention programs which aim to increase the RRS of emerging adults. Counselors working with the RRS of emerging adults can consider encouraging self-compassion as a way of increasing RRS level. Furthermore, university counseling centers can organize interventions in which self-compassion is encouraged. It is notably crucial to consider that the number of previous relationships is a significant predictor of satisfaction, as this suggests that psychological counselors should consider asking about previous relationship experiences if RRS issues occur. Moreover, it would be useful to utilize the non-significant findings of social appearance in doing more detailed research on cultural factors, since they are contradictory to most current literature. The possible reasons of this non-significance in today's world of social media can be investigated in further research. 


\section{REFERENCES}

Arnett, J. J. (2000). Emerging adulthood: A theory of development from the late teens through the twenties. American Psychologist, 55, 469-480. https://psycnet.apa.org/doi/10.1037/0003-066X.55.5.469

Baker, L. R., \& McNulty, J. K. (2011). Self-compassion and relationship maintenance: The moderating roles of conscientiousness and gender. Journal of Personality and Social Psychology, 100(5), 853-873. https://doi.org/10.1037/a0021884

Barry, C. M. N., Madsen, S. D., Nelson, L. J., Carroll, J. S., \& Badger, S. (2009). Friendship and romantic relationship qualities in emerging adulthood: Differential associations with identity development and achieved adulthood criteria. Journal of Adult Development, 16(4), 209-222. https://doi.org/10.1007/s10804-009-9067-X

Barry, C. T., Loflin, D. C., \& Doucette, H. (2015). Adolescent self- compassion: Associations with narcissism, self-esteem, aggression, and internalizing symptoms in at risk males. Personality and Individual Differences, 77, 118-123. https://doi.org/10.1016/j.paid.2014.12.036

Berscheid, E., Snyder, M., \& Omoto, A. M. (1989). Issues in studying relationships: Conceptualizing and measuring closeness. In C. Hendrick (Ed.), Close relationships: Review of personality and social psychology (pp. 63-91). Sage.

Biber, D. D., \& Ellis, R. (2019). The effect of self-compassion on the self-regulation of health behaviors: A systematic review. Journal of Health Psychology, 24(14), 2060-2071. https://doi.org/10.1177/1359105317713361

Bluth, K., \& Blanton, P. W. (2014). Mindfulness and self-compassion: Exploring pathways to adolescent emotional well-being. Journal of Child and Family Studies, 23(7), 1298-1309. https://doi.org/10. 1007/ s10826-013-9846-7

Bluth, K., Campo, R. A., Futch, W. S., \& Gaylord, S. A. (2017). Age and gender differences in the associations of self-compassion and emotional well-being in a large adolescent sample. Journal of Youth and Adolescence, 46(4), 840-853. https://doi.org/10.1007/s10964-016-0567-2

Bucher, A., Neubauer, A. B., Voss, A., \& Oetzbach, C. (2019). Together is better: Higher committed relationships increase life satisfaction and reduce loneliness. Journal of Happiness Studies, 20(8), 2445-2469. https://doi.org/10.1007/s10902-018-0057-1

Carver, K., Joyner, K., \& Udry, J. R. (2003). National estimates of adolescent romantic relationships. In P. Florsheim (Ed.), Adolescent romantic relations and sexual behavior: Theory, research, and practical implications (pp. 23-56). Lawrence Erlbaum.

Castilho, P., Carvalho, S. A., Marques, S., \& Pinto-Gouveia, J. (2017). Self-compassion and emotional intelligence in adolescence: A multigroup mediational study of the impact of shame memories on depressive symptoms. Journal of Child and Family Studies, 26(3), 759-768. https://doi.org/10.1007/s10826-016-0613-4

Claes, L., Hart, T. A., Smits, D., Van Den Eynde, F., Mueller, A., \& Mitchell, J. E. (2012). Validation of the social appearance anxiety scale in female eating disorder patients. European Eating Disorder Review, 20, 406409. https://doi.org/10.1002/erv.1147

Clark, M. S., \& Beck, L. A. (2011). Initiating and evaluating close relationships: A task central to emerging adults. In F. D. Fincham \& M. Cui (Eds.), Advances in personal relationships: Romantic relationships in emerging adulthood (pp. 190-212). Cambridge University Press.

Cohen, J. E. (1988). Statistical power analysis for the behavioral sciences. Lawrence Erlbaum Associates, Inc.

Coyne, S. M., Stockdale, L., Busby, D., Iverson, B., \& Grant, D. M. (2011). I luv u :): A descriptive study of the media use of individuals in romantic relationships. Family Relations, 60, 150-162. https://doi.org/10.1111/j.1741-3729.2010.00639.x

Cramer, D. (2004). Satisfaction with a romantic relationship, depression, support and conflict. Psychology and Psychotherapy, 77, 449-461. https://doi.org/10.1348/1476083042555389

Curun, F. (2001). The effects of sexism and sex role orientation on romantic relationship satisfaction. Unpublished master's thesis, Middle East Technical University, Ankara.

Deniz, M., Kesici, S., \& Sümer, A. S. (2008). The validity and reliability of the Turkish version of the SelfCompassion Scale. Social Behavior and Personality: An International Journal, 36(9), 1151-1160. https://doi.org/10.2224/sbp.2008.36.9.1151

Doğan, T. (2010). Adaptation of the Social Appearance Anxiety Scale (SAAS) to Turkish: A validity and reliability study. Hacettepe University Faculty of Education, 39, 151-159. https://dergipark.org.tr/tr/download/article-file/87464

Epstein, N. B., \& Baucom, D. H. (2002). Why couples are the way they are: Individual influences. In N. B. Epstein \& D. H. Baucom (Eds.), Enhanced cognitive-behavioral therapy for couples: A contextual approach (pp. 105-143). American Psychological Association. 
Frazier, P., \& Esterly, E. (1990). Correlates of relationship beliefs: Gender, relationship experience and relationship satisfaction. Journal of Social and Personal Relationships, 7, 331-352. https://doi.org/10.1074/jbc.272.2.843

Furman, W. (2002). The emerging field of adolescent romantic relationships. Current Directions in Psychological Science, 11(5), 117-180. https://doi.org/10.1111/1467-8721.00195

Ganem, P. A., Heer, H. D., \& Morera, O. F. (2009). Does body dissatisfaction predict mental health outcomes in a sample of predominantly Hispanic college students? Personality and Individual Differences, 46(4), 557-561. https://doi.org/10.1016/j.paid.2008.12.014

Gattario, K. H., \& Frisén, A. (2019). From negative to positive body image: Men's and women's journeys from early adolescence to emerging adulthood. Body Image, 28, 53-65. https://doi.org/10.1016/j.bodyim.2018.12.002

Goswami, S., Sachdeva, S., \& Sachdeva, R. (2012). Body image satisfaction among female college students. Industrial Psychiatry Journal, 21(2), 168-172. https://doi.org/10.4103/0972-6748.119653

Green, S. B. (1991). How many subjects does it take to do a regression analysis? Multivariate Behavioral Research, 26, 499-510. https://doi.org/10.1207/s15327906mbr2603_7

Grossbard, J. R., Lee, C. M., Neighbors, C., \& Larimer, M. E. (2009). Body image concerns and contingent selfesteem in male and female college students. Sex Roles, 60, 198-207. https://doi.org/10.1007/s11199-0089535-y

Gouveia, M. J., Canavarro, M. C., \& Moreira, H. (2019). Associations between mindfulness, self-compassion, difficulties in emotion regulation, and emotional eating among adolescents with overweight/obesity. Journal of Child and Family Studies, 28(1), 273-285. https://doi.org/10.1007/s10826-018-1239-5

Hart, T. A., Flora, D. B., Palyo, S. A., Fresco, D. M., Holle, C., \& Heimberg, R. G. (2008). Development and examination of the social appearance anxiety scale. Assessment, 15(1), 48-59. https://doi.org/10.1177/1073191107306673

Hendrick, S. S. (1988). A generic measure of relationship satisfaction. Journal of Marriage and Family, 50, 9398. https://doi.org/10.2307/352430

Kağıtçıbaşı, Ç. (2010). Benlik, aileve insane gelişimi: Kültürel psikoloji[Family, Self and Human Development Across Cultures].Koç Üniversitesi Yayınları [Koç University Press]

Kang, J. Y. M., Johnson, K. K. P., \& Kim, J. (2013). Clothing functions and use of clothing to alter mood. International Journal of Fashion Design, Technology and Education, 6(1), 43-52. https://doi.org/10.1080/17543266.2012.762428

Kırıt Gülaydın, G., \& Semerci, B. (2018). Examine the relationship satisfactions of adults who are experiencing a romantic relationship in terms of attachment styles, self-esteem and interpersonal relationship types. Psikoloji Araştırmaları, 3(6), 14-25.

Küçükarslan, M., \& Gizir, C. A. (2014). An investigation of university students' romantic relationship beliefs related to some variables. Turkish Psychological Counseling and Guidance Journal, 5(42), 148159.https://dergipark.org.tr/tr/pub/tpdrd/issue/21462/229981

Jacobson, E. H. K., Wilson, K. G., Kurz, A. S., \& Kellum, K. K. (2018). Examining self-compassion in romantic relationships. Journal of Contextual Behavioral Science, 8, 69-73. https://doi.org/10.1016/j.jcbs.2018.04.003.

Levinson, C. A., \& Rodebaugh, T. L. (2012). Social anxiety and eating disorder comorbidity: The role of negative social evaluation fears. Eating Behaviors, 13(1), 27-35. https://doi.org/10.1016/j.eatbeh.2011.11.006

Levinson, C. A., Rodebaugh, T. L., White, E. K., Menatti, A. R., Weeks, J. W., Lacovino, J. M., \& Warren, C. S. (2013). Social appearance anxiety, perfectionism, and fear of negative evaluation. Distinct or shared risk factors for social anxiety and eating disorders? Appetite, 67, 125-133. https://doi.org/10.1016/j.appet.2013.04.002

Lynch, T. R., Robins, C. J., \& Morse, J. Q. (2001). Couple functioning in depression: The roles of sociotropy and autonomy. Journal of Clinical Psychology, 57(1), 93-103. https://doi.org/10.1002/10974679(200101)57:1<93::AID-JCLP10>3.0.CO;2-6

Makadi, E., \& Koszycki, D. (2020). Exploring Connections Between Self-Compassion, Mindfulness, and Social Anxiety. Mindfulness, 11(2), 480-492. https://doi.org/10.1007/s12671-019-01270-z

Malouff, J. M., Schutte, N. S., \& Thorsteinsson, E. B. (2014). Trait emotional intelligence and romantic relationship satisfaction: A meta-analysis. The American Journal of Family Therapy, 42(1), 53-66. https://doi.org/10.1080/01926187.2012.748549

Mattson, R. E., Rogge, R. D., Johnson, M. D., Davidson, E. K. B., \& Fincham, F. D. (2013). The positive and negative semantic dimensions of relationship satisfaction. Personal Relationships, 20, 328-355. https://doi.org/10.1111/j.1475-6811.2012.01412.x

Mavruk Özbiçer, S., \& Atıcı, M. (2018). University students' emotional intelligence and romantic relationship satisfaction: A quantitative study. Journal of Human Sciences, 15(1), 265-279. https://www.jhumansciences.com/ojs/index.php/IJHS/article/view/5163 
Metts, S., \& Cupach, W.R. (1990). The influence of relationship beliefs and problem solving responses on satisfaction in romantic relationships. Human Communication Research, 17(1), 170-185. https://doi.org/10.1111/j.1468-2958.1990.tb00230.x

Neff, K. D. (2003a). Development and validation of a scale to measure self-compassion. Self and Identity, 2, 223250. https://doi.org/10.1080/15298860309027

Neff, K. D. (2003b). Self-compassion: An alternative conceptualization of a healthy attitude toward oneself. Self and Identity, 2, 85-102. https://doi.org/10.1080/15298860309032

Neff, K., \&Beretvas, S. (2013). The role of self-compassion in romantic relationships. Self and Identity, 12(1), 7898. https://doi.org/10.1080/15298868.2011.639548

Neff, K., \& Davidson, O. (2016). Self-compassion: Embracing suffering with kindness. In I. Ivtzan, \& T. Lomas (Eds.). Mindfulness in positive psychology: The science of meditation and wellbeing. Routledge.

Neff, K. D., \& McGehee, P. (2010). Self-compassion and psychological resilience among adolescents and young adults. Self and Identity, 9(3), 225-240. https://doi.org/10.1080/15298860902979307

Neff, K. D., Pisitsungkagarn, K., \& Hseih, Y. (2008). Self-compassion and self-construal in the United States, Thailand, and Taiwan. Journal of Cross-Cultural Psychology, 39(3), 267-285. https://doi.org/10.1177/0022022108314544

Neff, K. D., \& Vonk, R. (2009). Self-compassion versus global self-esteem: Two different ways of relating to oneself. Journal of Personality, 77(1), 23-50. https://doi.org/10.1111/j.1467-6494.2008.00537.x

Nock, S. L. (1995). Commitment and dependency in marriage. Journal of Marriage and Family, 57(2), 503-514. https://doi.org/10.2307/353702

Norona, J. C., Roberson, P. N. E., \& Welsh, D. P. (2017). "I learned things that make me happy, things that bring me down": Lessons from romantic relationships in adolescence and emerging adulthood. Journal of Adolescent Research, 32(2), 155-182. https://doi.org/10.1177/0743558415605166

Özcan, H., Subaşı, B., Budak, B., Çelik, M., Gürel, Ş. C., \& Yıldız, M. (2013). Relationship between self-esteem, social appearence anxiety, depression and anxiety in adolescent and young adult women. Journal of Mood Disorders, 3(3), 107-113. https://doi.org/10.5455/jmood.20130507015148

Paap, C. E., \& Gardner, R. M. (2011). Body image disturbance and relationship satisfaction among college students. Personality and Individual Differences, 51(6), https://doi.org/10.1016/j.paid.2011.06.019

Pintado, S., \& Mendoza, A. (2016). Attachment styles and relationship satisfaction. Revista de Psicología GEPU, 7(1), 157-168. https://revistadepsicologiagepu.es.tl/Attachment-Styles-and-Relationship-Satisfaction.htm

Pullmer, R., Coelho, J. S., \& Zaitsoff, S. L. (2019). Kindness begins with yourself: The role of self-compassion in adolescent body satisfaction and eating pathology. International Journal of Eating Disorders, 52(7), 809816. https://doi.org/10.1002/eat.23081

Rahaman, H. S. (2015). Romantic relationship length and its perceived quality: Mediating role of Facebook-related conflict. Europe's Journal of Psychology, 11(3), 395-405. https://doi.org/10.5964/ejop.v11i3.932

Roberts, B. W., \& Davis, J. P. (2016). Young adulthood is the crucible of personality development. Emerging Adulthood, 4, 318-326. https://doi.org/10.1177/2167696816653052

Roisman, G. I., Masten, A. S., Coatsworth, J. D., \& Tellegen, A. (2004). Salient and emerging developmental tasks in the transition to adulthood. Child Development, 75, 123-133. https://doi.org/10.1111/j.14678624.2004.00658.x

Sakalli-Ugurlu, N. (2003). How do romantic relationship satisfaction, gender stereotypes, and gender relate to future time orientation in romantic relationships?. The Journal of Psychology, 137(3), 294-303. https://doi.org/10.1080/00223980309600615

Saraç, A., Hamamcı, Z., \& Güçray, S. (2015). Predicting romantic relationship satisfaction of university students. Turkish Psychological Counseling and Guidance Journal, 5(43), 69-81. http://turkpdrdergisi.com/index.php/pdr/article/view/7/8

Seiffge-Krenke, I. (2003). Testing theories of romantic development from adolescence to young adulthood: Evidence of a developmental sequence. International Journal of Behavioral Development, 27(6), 519-531. https://doi.org/10.1080/01650250344000145

Sharma, S., \& Ahuja, K. K. (2014). Does love last forever? Understanding an elusive phenomenon among dating and married couples. Journal of Psychosocial Research, 9(1), 153-162.

Siegling, A. B., \& Delaney, M. E. (2013). Toward understanding body image importance: Individual differences in a Canadian sample of undergraduate students. Eating Disorders, 21(2), 117-129. https://doi.org/10.1080/10640266.2013.761083

Sira, N., \& White, C. P. (2010). Individual and familial correlates of body satisfaction in male and female college students. Journal of American College Health, 58(6), 507-514. https://doi.org/ $10.1080 / 07448481003621742$ 
Stolarski, M., Wojtkowska, K., \& Kwiecińska, M. (2016). Time for love: Partners' time perspectives predict relationship satisfaction in romantic heterosexual couples. Time \& Society, 25(3), 552-574. https://doi.org/10.1177/0961463X15596703

Svendsen, J. L., Kvernenes, K. V., Wiker, A. S., \& Dundas, I. (2017). Mechanisms of mindfulness: Rumination and self-compassion. Nordic Psychology, 69(2), 71-82. https://doi.org/10.1080/19012276.2016.1171730

Szymanski, D. M., \& Henning, S. L. (2007). The role of self-objectification in women's depression: A test of objectification theory. Sex Roles, 56(1-2), 45-53. https://doi.org/10.1007/s11199-006-9147-3

Tabachnick, B. G., \& Fidell, L. S. (2007). Using multivariate statistics. Allyn \& Bacon.

Taormina, R. J., \& Ho, I. K. (2012). Intimate relationships in China: Predictors across genders for dating, engaged, and married individuals. Journal of Relationships Research, 3, 24-43. https://doi.org/10.1017/jrr.2012.5

Titchener, K., \& Wong, Q. J. J. (2015). A weighty issue: Explaining the association between body mass index and appearance-based social anxiety. Eating Behaviors, 16, https://doi.org/10.1016/j.eatbeh.2014.10.005

Vaughn, M. J., \& Baier, M. E. M. (1999). Reliability and validity of the relationship assessment scale. American Journal of Family Therapy, 27(2), 137-147. https://doi.org/10.1080/019261899262023

Wasylkiw, L., MacKinnon, A. L., \& MacLellan, A. M. (2012). Exploring the link between self-compassion and body image in university women. Body Image, 9(2), 236-245. https://doi.org/10.1016/j.bodyim.2012.01.007

Wiik, K. A., Bernhardt, E., \& Noack, T. (2009). A study of commitment and relationship quality in Sweden and Norway. Journal of Marriage and Family, 71(3), 465-477. https://doi.org/10.1111/j.17413737.2009.00613.x

Wurst, S. N., Gerlach, T. M., Dufner, M., Rauthmann, J. F., Grosz, M. P., Küfner, A. C. P., Denissen, J. J. A., Back, M. D. (2017). Narcissism and romantic relationships: The differential impact of narcissistic admiration and rivalry. Journal of Personality and Social Psychology, 112(2), 280-306. https://doi.org/10.1037/pspp0000113

Yerin-Güneri, O., Hatipoğlu-Sümer, Z., \& Yıldırım, A. (1999). Sources of self-identity among Turkish adolescents. Adolescence, 34(135), 535-546. https://eric.ed.gov/?id=EJ610953

Zimmer-Gembeck, M. J., \& Petherick, J. (2006). Intimacy dating goals and relationship satisfaction during adolescence and emerging adulthood: Identity formation, age and sex as moderators. International Journal of Behavioral Development, 30(2), 167-177. https://doi.org/10.1177\%2F0165025406063636 


\section{TÜRKÇE GENIŞLETILMISŞ ÖZET}

İlişki doyumu, bir bireyin ilişkisiyle ilgili genel memnuniyet düzeyini ifade eder (Mattson vd., 2013). Beliren yetişkinlik dönemi, gelecekte sağlıklı romantik ilișkilerin kurulması ve sürdürülmesinde özellikle önemlidir, çünkü beliren yetişkinlik döneminde kazanılan deneyim, sonraki romantik ilişkilere olan bağll1ı̆̆ın kalitesini ve seviyesini etkiler (Furman, 2002). Beliren yetişkinlik dönemindeki ilişkilerde, kişinin gelecekteki romantik partnerini bulması için hissettiği bağlılık, ilişkiye ayırdığ1 zaman ve duyguların paylaşımı ilişki doyumunun belirlenmesinde önemlidir (Arnett, 2000). Yapılan araştırmalar ilişki doyumunu etkileyen pek çok faktör olduğunu göstermektedir. Yaşam doyumu, psikolojik iyi oluş, problem çözme becerileri, empatik davranma ve güvenli bağlanma stili, duygusal zeka gibi faktörlerin yanı sıra önceki iliş̧ki deneyimleri, bir kişinin mevcut bir ilişkiden ne kadar memnun olduğu, ilişkinin uzunluğu, ilişkinin statüsü, önceki ilişkilerinin sayısı gibi çeşitli ilişki özellikleri de bireylerin şimdiki ilişkilerinde hissettikleri doyumu etkileyen faktörler olarak karşımıza çımaktadır (Epstein ve Baucom, 2002; Malouff vd., 2014; Metts ve Cupach, 1990; Pintado ve Mendoza, 2016; Roberts ve Davis, 2016; Saraç vd., 2015).

İlişki özelliklerinin yanı sıra, kendini yargılamadan nezaket ve anlayış gösterme anlamına gelen özşefkat (Neff, 2003b), sağlıklı ve tatmin edici bir ilişsi için önemli unsurlardan biridir. Öz-şefkat, romantik ilişkide partnerlerin duygusal bağlılığını güçlendirmeye, sorunlarla başa çıkmak için yapıcı bir ortam yaratmaya ve karşılıklı kabulün artmasına katkı sağlar (Neff ve Beretvas, 2013). Tam tersine, kendini sürekli eleştiriyor olmak, ilişkilere olumsuz yansımaktadır (Lynch vd., 2001). Başka bir önemli bir nokta da öz-şefkati yüksek bireylerin hem kendilerinin hem de partnerlerinin ilişkiye yaptıkları yatırım yüksektir. Bu sayede bireyler, herhangi bir çatışma yaşadığında konuyu daha anlaşılır yollarla ele alabilirler.

Beliren yetişkinlik döneminde, sosyal görünüş kaygısı da ilişki doyumunda önemli bir faktör olarak karşımıza çıkmaktadır. Bu yaş grubundaki bireyler fiziksel çekiciliğe önem verdiği için, özellikle dış görünüşe büyük önem atfetmektedir (Titchener ve Wong, 2015). Sosyal görünüş kaygısı ile bireylerin kendini kabul, öz-şefkat gibi özelliklerini arasında ters yönde bir ilişki bulunmaktadır (Wasylkiw vd., 2012). Alan yazın ışığında, beliren yetişkinlik döneminde ilişki doyumunun önemi düşünüldüğünde, bu çalışmanın amacı, ilişki özellikleri, öz-şefkat ve sosyal görünüm kaygısının ilişki doyumunu yordamadaki rolünün incelenmesidir. Bu bağlamda modele önce ilişki özellikleri, ikinci basamakta özşefkat ve üçüncü basamakta da sosyal görünüm kaygısı dahil edilerek ayrı ayrı yordama gücüne bakılmıştır.

Bu araştırmaya uygun örnekleme yöntemiyle iki ayrı devlet üniversitesinden 250 (149 kadın, 101 erkek) öğrenci katılmıştır. Katılımcıların yaşı 18 ila 25 arasında değişmektedir. Katılımcıların ortalama ilişki süresi 23.07 aydır. Katılımcıların ilişkilerinin onlar için önemi 7'li derecelendirme ölçeği (1: önemli değil; 7: çok önemli) üzerinde sorulmuş ve ortalama 5.97 bulunmuştur. Katılımcıların \% 91.2'si ilişki statülerini kız-erkek arkadaş olarak belirtirken, \% 8.8'i nişanlı olduğunu ifade etmiştir. Araştırmada veri toplama aracı olarak, İlişki Doyumu Ölçeği (Hendrick, 1988), Öz-şefkat Ölçeği (Neff, 2003a) ve Sosyal Görünüm Kaygısı Ölçeği (Hart vd., 2008) kullanılmıştır. Üniversitenin Etik Kurulu'ndan onay alındıktan sonra, öğretim üyeleriyle iletişime geçilmiş ve derslerinde anket uygulaması yapmak izin izin alınmıştır. Araştırmacılar, sınıflara giderek öğrencileri çalışmanın amacı hakkında bilgilendirmiştir. Çalışmaya katılmayı kabul eden öğrencilere onam formu dağıtılmış, imzalatılan onam formları toplandıktan sonra ise anket formları verilmiştir. Öğrencilerin anketleri doldurmaları yaklaşı $20 \mathrm{dk}$ sürmüştür.

Araştırmada ilişki özellikleri, öz-şefkat ve sosyal görünüm kaygısının romantik ilişki doyumunun yordayıcıları olup olmadığını test etmek amacıyla hiyerarşik regresyon analizi yapılmıştır. İlk aşamada modele ilişki özellikleri dahil edilmiştir. İlişkinin önemi $(\beta=0.59, p<0.001)$ ve daha önceki ilişki sayısı $(\beta=0.12, p<0.05)$ anlamlı yordayıcılar olarak bulunurken, ilişkinin uzunluğu $(\beta=0.04, p>0.05)$ ve 
ilişkinin statüsü $(\beta=0.06, p>0.05)$ anlamlı yordayıcılar olarak bulunmamıştır. Sonuçlar, ikinci olarak modele eklenen öz-şefkatin anlamlı bir yordayıcı olduğunu göstermiştir $(\beta=0.16, p<0.05)$. Son olarak, üçüncü aşamada eklenen sosyal görünüm kaygısının ise romantik ilişki doyumunu yordayan bir değişken olmadığı bulunmuştur $(\beta=-.09, p>.05)$. Tüm model romantik ilişki doyumunun \% 37 'sini açıklamıştır ve modelin etki büyüklüğü 0.58 olarak bulunmuştur.

Genel olarak, araştırma bulguları, ilişkinin öneminin modele en çok katkıda bulunan değişken olduğunu ve en yüksek ikinci katkıyı öz-şefkatin yaptığını ortaya koymaktadır. Öte yandan, önceki romantik ilişkilerin sayısı modele en az katkı yapan değişken olmuştur. Bu bulgulardan yola çıkarak, özellikle beliren yetişkinlik döneminde olan bireylerin ilişkilerine ne kadar önem atfettiği, öz-şefkat düzeyleri ve önceki romantik ilişkilerinin sayısının romantik ilişki doyumunun güçlendirilmesinde rol oynayabileceği göz önünde bulundurulmalıdır.

Araştırmanın önemli bulgularından birisi, daha önce çok fazla araştırılmamış olan ilişkiye verilen önemin, beliren yetişkinlik döneminde ilişki doyumunu anlamlı şekilde yordamasıdır. Ayrıca bulgulardan hareketle, beliren yetişkinlerin önceki ilişkilerinin sayısı ne kadar fazlaysa, tarzları ve mevcut ilişkilerini nasıl yürüttükleri hakkında bilgi sahibi olma olasılıkları o kadar arttığı sonucuna varılabilir. Araştırmada, sosyal görünüm kaygısının anlamlı bir yordayıcı olmadığı şaşırtıcı bir bulgudur. Örnek vermek gerekirse, Türkiye'nin dahil doğu kültürleri, görünüşleri veya ilişkileri dahil olmak üzere genç yetişkinlerin yaşam tercihlerine daha fazla müdahale etme eğilimindedir. Üniversite öğrencilerinin çoğu üniversiteye başladıklarında ailelerini ilk kez terk ederler ve daha sonra ailenin baskısı ortadan kalktıkça hayat seçimlerinde bir özgürlük duygusu hissedebilirler. Dolayısıyla öğrencilerin sosyal görünümlerini ilişki doyumu açısından önemsemediği düşünülebilir.

Araştırma bazı sınırlılıklar bulunmaktadır. Öncelikle araştırmaya yalnızca iki üniversiteden öğrenciler katıldığg için sonuçların tüm beliren yetişkinlere genellenmesi sınırlıdır ve araştırma ilişsisel desende tasarlandığ için neden-sonuç ilişkisi elde edilmemektedir. Sonraki araştırmalarda, boylamsal çalışmaların yapılması ve açıklanmayan varyansın belirlenmesi için farklı ilgili değişkenlerin romantik ilişki doyumunun yordanmasında araştırmaya dahil edilmesi önerilmektedir. 